justify his actions as not being discriminatory. Finally, it would seem reasonable to require a greater precision and certainty of proof when an action is brought against a private person than when brought against the state.

The conflict between free choice and equality which is created by the enactment and the enforcement of anti-discrimination measures will exist as long as racial, religious, and other forms of group prejudices endure in our society. While the fact that discrimination is not susceptible of certain proof may heighten this conflict, a judicious establishment of the requirements of proof and a skillful manipulation of the burdens created by these requirements may serve to prevent the engulfing of either ideal by the other.

\title{
DETERMINATION OF JUST COMPENSATION IN A CONTROLLED MARKET
}

When private property is taken for public use, the usual measure of "just compensation"1 is "market value."2 The justice of this measure in a free market appears manifest: "These market values, being the result of competitive purchase by persons free to utilize purchasing power as they please, may be accepted as measuring roughly the relative importance (for the community) of physical units of different things." 3

However, when the government requisitions commodities in wartime, the adequacy of the normal rule is challenged by three different market situations.

First, the wartime market reflects "unusual" economic circumstances involving "abnormal" conditions of supply and demand, and it may be argued that these abnormalities should be recognized in a court's finding of just compensation. In C. G. Blake Co. v. United States, ${ }^{4}$ a case arising out of World War I, the government maintained that "on account of abnormal conditions, resulting from the war ... there was no true or fair market, and no such thing as fair market value. ..." The court held, however, that "fair market value" does not necessarily mean value in "a market in which the supply about equals the demand, and in which conditions might be termed fairly normal. . . ." Such wartime economic abnormalities provide no greater reason to suspend the market value rule than comparable abnormalities in peacetime:

" "... nor shall private property be taken for public use, without just compensation." U.S. Const. Amend. 5.

2 The phrases "market value" and "just compensation" have been used interchangeably to such a degree that Nichols declares, "Market value, and market value alone, is the universal test." I Nichols, Eminent Domain 663 (2d ed. I9I7); see 2 Lewis, Eminent Domain $\& 706$ ( 3 d ed. $190 \mathrm{~g}$ ). The current view is that "market value is simple the ordinary test, to be rejected in those exceptional cases where it would not constitute 'just compensation.' " Orgel, Valuation Under Eminent Domain 60 (1936).

${ }^{8}$ Simons, Economic Policy for a Free Society 46 (1948).

4275 Fed. 86I (D. C. Ohio, I92I).

5 Ibid., at 862.

${ }^{6}$ Tbid., at 866. 
Drouths, floods, commercial panics, crop failures, labor difficulties, and other causes frequently affect markets seriously, but not so as to warrant a court, when assessing compensation consequent upon the exercise of the right of eminent domain, in saying that there is no market. The effects of war may differ in degree, but, so long as a market-that is, a general buying and selling of the commodity-exists, the rule persists. ${ }^{7}$

If market value is just compensation because it is the measure of value freely arrived at by the community in the course of competitive buying and selling, the result of the Blake case surely follows. ${ }^{8}$

The second and third wartime challenges to the market value rule arose in the recent war because the characteristic market situation was not one in which price was competitively determined. Either the commodities taken were subject to government price control under OPA regulations; or, because of their peculiar importance to war production, the commodities taken were subject to stringent government market controls which effected virtual suspension of trade in normal volume. In the former case, it was urged that the rationale of the market value rule, based on the assumption of a free market, could not be applied to the OPA ceiling price; in the latter situation, it was argued that there was simply no market price to turn to.

The Supreme Court has never ruled squarely on the question whether a ceiling price constitutes just compensation. In United States v. Felin \& Co., Inc., ${ }^{9}$ Justice Reed, in a concurring opinion, characterized the constitutionally established ceiling price as "the only relevant measure of just compensation."10 Joined by Justices Black and Murphy, he argued that the government could constitutionally require owners of this perishable property either to sell at the fixed price or not to sell at all. "If the Government fixed prices with the predominant purpose of acquiring property affected by its order, a different situation would be presented." 11 But here was price regulation affecting buying

I Ibid., at 864. Insofar as the Blake case indicated that the courts should disregard government regulations and priorities in fixing just compensation in wartime, the Circuit Court of Appeals for the Second Circuit expressly refused to follow it in a case involving the valuation of land. United States v. Delano Park Homes, Inc., I46 F. 2d 473, 474 (C.C.A. 2d, 1944).

${ }^{8}$ The Supreme Court approved this line of reasoning in United States v. New River Collieries Co., 262 U.S. $34^{\mathrm{I}}$ (I923). No case in the recent war appears to have challenged the market value rule solely on the basis of alleged economic abnormalities. Having imposed direct economic controls earlier and on a broader scale than in World War $I$, the government has argued that the various prices prevailing under such controls were the measures of just compensation for commodities taken.

${ }^{9} 334$ U.S. 624 (I948). In World War $\mathrm{T}$, the prevailing price for copper fixed and enforced by the government in cooperation with copper processors was held by the Supreme Court to be just compensation for copper requisitioned by the government, when the owner had actively assisted in setting the price and enforcing compliance. Vogelstein \& Co., Inc. v. United States, 262 U.S. 337 (1923).

${ }^{10} 334$ U.S. 624, 646 (I948). Justice Reed cites Vogelstein \& Co., Inc. v. United States, 262 U.S. 337 (I923), as authority for the statement that the "prevailing price in a controlled market was 'just compensation." " 334 U.S. 624, 645 (I948).

11 United States v. Felin \& Co., Inc., 334 U.S. 624, 646 (I948). 
and selling on a national scale. To require the government in this situation to pay a higher price for requisitioned property than that legally obtainable from the general public would be "anomalous,"12 especially when the regulations were themselves subject to judicial review. ${ }^{13}$

Justice Frankfurter, joined by the Chief Justice and Justice Burton in the majority opinion, upheld the government's award of ceiling price as just compensation on other grounds. The majority declared that the burden was upon the complainant to prove that the original government award was less than just compensation, and that, since it had not done so, the Court need not consider the controversial question as to whether a fixed market price was of itself just compensation. ${ }^{14}$ As to that question, however, Justice Frankfurter indicated disagreement with the Reed view that controlled selling price was just compensation because it was the maximum price legally obtainable in the prevailing market. ${ }^{15}$ While market price is the conventional criterion, ". . . there must be a market to make the criterion available. Here there was a market ... but it was not a free and open market; it was controlled in its vital feature, selling price, by the OPA."16

In a second concurring opinion, Justice Rutledge, remarking that the Reed view "may be" correct in the case of highly perishable property, held that the ceiling price itself furnished at least a presumptive measure of just compensation which must be allowed to stand in the present case, the complainant not having overcome the presumption with a showing of compensable loss. ${ }^{17}$ Justices Jackson and Douglas dissented:

[M]arket price, as such, is not controlling. The Fifth Amendment's "exact limitation on the power of the Government" is not market price-it is just compensation. The former is relevant, and this Court has so considered it, only because, in a free market, it is perhaps the best key to value at the time of taking. ${ }^{18}$

The dissent believed that if the ceiling price were found to be just compensation in this case, it would thereafter be necessary for all ceiling prices to meet the constitutional requirement of just compensation to be valid. ${ }^{19}$ This would of course be an intolerable burden upon the administration of price controls. The purpose of the price control act was "to prevent speculative,

12 Ibid., at 645 .

${ }^{13}$ Justice Reed places some emphasis upon the fact that perishable goods were involved in the Felin case. This leaves open the question whether ceiling price should be the measure of just compensation for goods the owner might retain without risking spoilage. If an owner of such goods were to decide to retain his goods until the lifting of ceilings, the ceiling price would not necessarily be the maximum price legally obtainable. Compare Pantex Pressing Machine, Inc. v. United States, 7 I F. Supp. 859, 862 (Ct. Cl., I947).

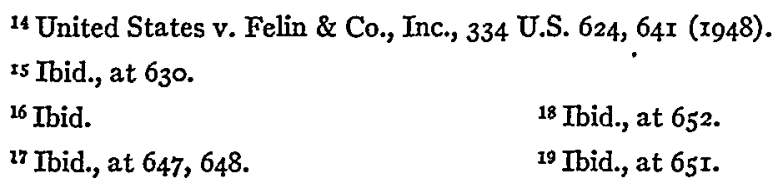


unwarranted, and abnormal increases in prices and rents; to eliminate and prevent profiteering, hoarding, manipulation, speculation, and other disruptive practises resulting from abnormal market conditions"20 of wartime; just compensation, on the other hand, has sometimes required an award of "unwarranted" prices in "abnormal" markets. ${ }^{21}$

The Felin case poses the problem. If market price is just compensation because it is the best measure of value in a free market, some other measure of value is required when the government enforces a fixed ceiling price. If market price is just because it is the highest price legally obtainable in the prevailing market, a government ceiling price qualifies as just compensation, provided the price has not been fixed with the predominant purpose of acquiring for public use the property affected. In no case can the ceiling price be defended as just compensation merely because anything higher would be "abnormal" according to the standards of a congressional price control act.

If the courts adopt the view which justifies market prices only if there is a free market, the problem of finding substitute measures of value arises in any situation in which the market is regulated. The difficulties barring a solution of this problem appear in a third type of case, where the government requisitions commodities which, because of their importance to the war, have been placed under close government trading controls. These controls not only restrict the free determination of price as do simple price controls, but, in addition, severely limit the amount of trading in the controlled market. For example, during the recent war the use or sale of aluminum for any but authorized purposes was forbidden by government order. To channel into essential war production the goods made idle by this order, the government offered to purchase aluminum inventories at a price that was 75 per cent of the market listings, feeling that in the light of the regulations and uncertainties of wartime, such a price was sufficient to induce voluntary sales by the holders of aluminum. ${ }^{22}$

${ }^{20}$ Emergency Price Control Act, 56 Stat. 23, 24 ( 1942 ). The price control act also sought to "assure that defense appropriations are not dissipated by excessive prices." Thid.

${ }_{21}$ United States v. New River Collieries Co., 262 U.S. 34I (r923); C. G. Blake Co. v. United States, 275 Fed. 86r (D.C. Ohio, I92r); National City Bank of New York v. United States, 275 Fed. 855 (D.C. N.Y., I92I). However, the owner cannot trade on the necessities of the government by demanding "strategic value" for his property. United States v. ChandlerDunbar Water Power Co., 229 U.S. 53 (I9I3); cf. Lawrence v. Boston, IIg Mass. r26 (I875). Nor will the courts recognize a price manipulated by the owner of the property. Lovejoy $v$. Michels, 88 Mich. I5, 27, 49 N.W. goI, 903, 904 (I89I); cf. Muser v. Magone, I55 U.S. 240 (1894).

In Walker v. United States, 64 F. Supp. 135, I40 (Ct. Cl., I946), the Court of Claims disregarded the fundamental distinction in objectives between congressional enactments to control inflation through price ceilings and judicial determinations of value for just compensation purposes. Without exploring the question as to whether the ceiling price was of itself just compensation, the court said that it was not surprising that just compensation, judicially determined, and ceiling price, administratively fixed, should turn out to be equivalent, "in view of the statutory basis by which the Administrator was bound."

${ }_{22}$ Illinois Pure Aluminum Co. v. United States, 67 F. Supp. 955, 957 (Ct. C1., I946). 
In Pantex Pressing Machine, Inc. v. United States, ${ }^{23}$ the government argued that the purchase program price was the measure of just compensation for requisitioned aluminum. But the Court of Claims held that "the fact that 98 per cent of the holders of aluminum in this country turned over to the Government 96 per cent of their holdings at this price ... did not establish a market"24 such as would qualify the price as just compensation. In the absence of a determinable market value, the court adopted, as the nominal measure of just compensation, "retention value," which is described as follows:

While the Government ... . has the unquestioned right to impose restrictions ... nevertheless when it takes a person's property it must compensate him in the light of his right to retain his property, unless requisitioned until the restrictions on its use and disposition should be removed. If it is possible to ascertain the market value of the property at the time of the taking, a plaintiff is entitled to recover this value, less these carrying charges. This is what the defendant aptly calls "retention value."2s

Of course, the inability of the courts to determine "market value of the property at the time of the taking" is responsible for the confusion in these cases. After rejecting the various figures suggested by the parties as the proper "market value" in this case, the court held that the plaintiff was entitled to an award of cost plus a "fair mark-up for profit." The court concluded, saying, "There is no testimony covering profit and other expenses and carrying charges, but we think it fair and equitable to conclude that one would about offset the other." In effect, then, original cost provided the measure of value in this case. 27

Once market price is abandoned as the measure of value, it seems clear that

${ }^{23} 7$ I F. Supp. 859 (Ct. Cl., 1947).

24 Ibid., at 862. Contra: Lessner Plumbing \& Heating Co., Inc. v. United States, 64 F. Supp. 93I, 934 (N.Y., I945). Compare Graves v. United States, 62 F. Supp. 23I, 234 (N.Y. I945), where just compensation was the "best available market for plaintiffs' property on the date of the taking" which was the Copper Recovery Program purchase price. Only these two federal district court cases have upheld such prices as market value. Compare Louisiville Flying Service, Inc. v. United States, 64 F. Supp. 938 (Ky., I945).

${ }^{25}$ Pantex Pressing Machine, Inc. v. United States, 7I F. Supp. 859, 862 (Ct. Cl., I947). ${ }^{26}$ Ibid., at 863 .

${ }^{27}$ It is significant that the court assumed that a substitute measure for market value should include, in addition to cost, a fair profit. In application of the usual rule, loss of business good will, or profits, incidental to a taking, are generally held not to be compensable, either on the ground that such loss is not a part of the value of the property taken, or that such losses are too speculative to be considered. Orgel, Valuation Under Eminent Domain $\$ \S 71,74,75,76$ (1936). In the Blake case, the court denied a cost-plus-reasonable-profit measure suggested there by the government. It said plaintiff was entitled to a "full and just equivalent," but, "Cost plus a reasonable profit may be more or less than an equivalent. . ." C. G. Blake Co. v. United States, 275 Fed. 86r, 867 (D.C. Ohio, I921).

In Neumaticos Goodyear, S.A. v. United States, 73 F. Supp. 969, 972 (Ct. Cl., 1947), just compensation was found to be the average of many individually computed prices, which had been paid by the government in its purchases of idle rubber under the Surplus Stocks Program, plus a "fair mark-up for profit, to which we think it is entitled considering the risk incurred in the purchase and shipment of the rubber." 
some type of cost figure must be adopted: original cost; out-of-pocket costs (analogous to reliance damages); cost plus a "fair" mark-up for profit (approximating expectation damages); or replacement cost, as was suggested in the Felin case. ${ }^{28}$ The difficulty with replacement cost in most of these wartime cases is that it may be impossible to replace the requisitioned property at any price, and the attempt to compute what replacement cost would be may lead a court into the very type of conjecture which it must seek to avoid. If a court attempts to use original cost, it will undoubtedly find itself confronted with several alternative cost figures each based on a different set of accounting assumptions, and each valid, given its own premises. ${ }^{29}$ In any case, a measure of value based upon cost cannot be as satisfactory a measure as that based upon market price. To move from price to cost in the determination of value is to move out of the market place and onto the balance sheet, where the "speculative approximation and guesswork"30 of cost accountancy reign. A reasonably objective measure is replaced by a relatively subjective one.

The difficulties encountered in determining just compensation from a consideration of such subjective factors can be seen in the failure of the courts in some cases to articulate the basis of their findings. ${ }^{31}$ To avoid these difficulties and preserve the virtues of the market value rule, the court in one case ${ }^{32}$ treated the market price prevailing before the imposition of controls as the value of the property at the time of the taking. Considering the uncertainties

${ }^{28}$ Replacement cost was the measure adopted by the Court of Claims. Felin \& Co., Inc. v. United States, 67 F. Supp. IoI 7 (Ct. Cl., r946). The property involved was a quantity of pork products. In view of the problem of joint costs in a business producing no single major product, Justice Frankfurter ruled replacement cost to be a "spurious" measure of value. United States v. Felin \& Co., Inc., 334 U.S. $624,632,640$ (1948).

${ }^{29}$ For example, the cost of inventories may be priced under LIFO, FIFO, or averaging methods of accounting. The costs of identical commodities could thus differ by wide margins, according to the system employed. When there is a determinable market value, there may be a great divergence between the cost and value figures. There would probably be even greater disagreement and confusion over the original cost of "joint-cost" products. See opinion of Justice Frankfurter in United States v. Felin \& Co., Inc., 334 U.S. 624-42 (I948). Compare Hamilton, Cost as a Standard for Price, 4 Law \& Contemp. Prob. 321 (I937).

30 United States v. Felin \& Co., Inc., 334 U.S. 624,634 (1948).

31 In Harris \& Co. v. United States, 69 F. Supp. I29 (Ct. Cl., I947), the plaintiff had held a contract, subsequently cancelled because of government regulations, to sell metal rods at $\$ 5.50$ per cwt. Later, when the OPA approval of sales was required, that body allowed a sale of part of this stock at $\$ 3.47$ per cwt. An OPA ceiling was then established at $\$ 2.75$ per cwt. The "fair and reasonable value" of the rods upon requisitioning was found to be $\$ 3.23$ per cwt. Although the court took notice of some deterioration in the metal, it did not reveal the basis of its figure, which is two-thirds the way from the $\$ 2.75$ ceiling to the $\$ 3.47$ authorized selling price.

In Illinois Pure Aluminum Co. v. United States, 67 F. Supp. 955 (Ct. Cl., 1946), the court found just compensation "from all the facts and the circumstances" of the case to be $\$ 36,420$.ro, where original cost had been $\$ 45,918.07$; replacement cost, $\$ 42,847$.I8; the original government award, based on its purchase program price, $\$ 30,78 \mathrm{r} .83$; and the plaintiff's claim, $\$ 45,045.25$. Again, the basis of this valuation is not revealed.

${ }^{32}$ Arkansas Valley Ry., Inc. v. United States, 68 F. Supp 727 (Ct. Cl., I946). 
inherent in the alternative method of cost valuation, can it be conclusively demonstrated that the last prevailing free price is less satisfactory as a measure of value?

But an orderly approach to the problem of valuation for just compensation in a regulated market is possible. The rationale which attempts to explain the market value rule in terms of competitive buying in a free market should be abandoned. It is suggested, rather, that under the logic which requires compensation to be "just to the public as well as to the owner,"33 market value should be viewed as just compensation because it awards the owner the best price he could obtain for his property in the general market, at the same time placing a limit on the price which the public (i.e., the government) must pay. It is also the most objective and most easily determined standard of value. According to this rule, in a competitive but inflated (or deflated) market, the measure of just compensation is the prevailing market price, although such price may seem "abnormally" high (or low) relative to the owner's costs and his prospective profits (or losses).

This rule should be extended to the controlled market, where the government fixes the ceiling price at which trading may proceed: the prevailing market price, although probably the ceiling price, is the appropriate measure. It has never been considered important that a particular market price may reflect market control by a monopolist. ${ }^{34}$ If the government should adopt antiinflation market controls in the course of war, the prevailing price in such a controlled market should be accepted as the appropriate measure of value. It is an objective standard, provided the predominant purpose of the government is not to acquire property at the fixed prices. It is easily determined, and it awards the owner the maximum legal price obtainable for the property, without the necessity of resorting to hypothetical "markets."

The owner may argue that, were it not for the taking, he would have a right to retain his property until the restrictions were lifted, at which time, presumably, the property could be used or sold to better advantage than presently possible; and that this right to retain is an element of value to be compensated for. The answer to this argument is that, since neither the time during which controls will be continued nor the state of the market at the expiration of controls can be accurately determined, the value of the right to retain is speculative, to say the least. Assuming, however, that the right to retain could be accurately valued, an award of such value would result in discrimination in

${ }^{32}$ C. G. Blake Co. v. United States, 275 Fed. $86 \mathrm{r}, 867$ (D.C. Ohio, I92I). Compare the Second War Powers Act of 1942 , which restricted compensation for taking to that which the Fifth Amendment enjoins. 56 Stat. I76, x8I (I942), 50 App. U.S.C.A. $\$ \$ 63 I, 636 a$ (I944).

${ }^{34}$ See Illinois Pure Aluminum Co. v. United States, 67 F. Supp. 955, 957 (Ct. Cl., I946), where it is said, "For a number of years the market price for aluminum was largely governed by the price list of the Aluminum Corporation of America, which controls a large part of the production of aluminum. From this company most of the users of aluminum secured their supplies." Presumably, absent the wartime regulations, such market price would be just compensation within the terms of the Fifth Amendment. 
favor of those whose property is taken by eminent domain, against those who sold on the market at the fixed ceiling price. ${ }^{35}$

In the Court of Claims, Judge Madden has written, in dissent, a strong argument for treating a fixed market price as the proper measure of just compensation:

The Court holds that the Government ... to make just compensation, must pay more than its valid law would have permitted anyone else to pay. And the evidence on which the higher price is based is that, before the price was put under control, the higher price prevailed, and that, in the opinion of an expert, when price control should have been removed, the higher price would, again, prevail.

This evidence does not seem to me to be helpful. Pecuniary values are the product of many factors, and, particularly in wartime, some of the most important factors are the actions of Government.... [T] hese factors are actual, and lawful, and, I think, should not be disregarded by resort to a hypothetical situation in which they do not exist. Besides, I think it is inequitable and discriminatory ... to pay the person, whose property happened to be requisitioned by the Government, more than his fellow, who sold his property in the market, could lawfully charge or accept. ${ }^{36}$

As noted previously, the "lawful actions of Government" in the wartime market may extend beyond the anti-inflation measures of price-fixing. When the government prohibits the use or sale of vital materials for any but authorized purposes, and, having thus limited the market, establishes a "program price" at which it is hoped the goods will voluntarily flow to authorized users, the proper measure of just compensation under the suggested rationale would be the program price. This would be true although it be shown that the government had fixed a price lower than that which prevailed on the free market immediately before the imposition of controls. The predominant purpose was not to take the property affected by the controls; it was to establish the least inflationary price at which transfers of vital goods would expeditiously be made to authorized war contractors. ${ }^{37}$ This being so, the price can be said to be a reasonably objective measure of value; it is easily determined; it awards the

${ }^{35}$ In addition, it should be remembered that in establishing price control, Congress provided means of direct attack upon those ceilings which appeared unjust to affected owners. Compare Justice Reed's opinion in United States v. Felin \& Co., Inc., 334 U.S. 624, 646 (r948). In United States v. Delano Park Homes, Inc., I46 F. 2d 473, 474 (C.C A. 2d, I944), the issue involved the effect to be given government building priorities in valuing land which the owner had intended to use in a housing program. Judge L. Hand said, "When competent authority has fixed prices at a maximum, or has denied owners some specific use of their property, it is patently a disregard of its authority ... to allow the price to be figured in disregard of the limitation imposed." It is suggested in OPA Ceiling Prices as Evidence of Value, 6o Harv. L. Rev. ${ }^{32}$, I33 (1946), that the "prohibition of the Act against selling ... in violation of OPA price regulations might be ... applicable to requisitions ... . since 'selling' is defined to include 'sales, dispositions, exchanges, leases, and other transfers.' "

${ }^{38}$ Arkansas Valley Ry., Inc. v. United States, 68 F. Supp. 727, 73I (I946).

${ }^{37}$ In case of aluminum, 98 per cent of the holders of aluminum stocks in this country sold 96 per cent of their holdings to the government at such a program price. Pantex Pressing Machine, Inc. v. United States, 7 I F. Supp. 859, 862 (Ct. Cl., I947). 
owner the maximum price legally obtainable in the market; and it avoids confusing expeditions into the realm of cost accountancy.

A final, but unlikely, hypothetical case may be dealt with. Were the government, in a proper situation, to impose unqualified restrictions upon the use or sale of given property, the value of such property would be zero if the "right to retain" until the lifting of restrictions were denied. Under the analysis adopted here, "just compensation" would require the government to pay the owner no more than the value of the property at the time of taking, i.e., zero. Before it is objected that such a result would be as unconscionable as the case would be unlikely, it should be pointed out that the government may, by valid restrictions, destroy property value and not be required to compensate for such destruction. For example, the refusal of the government to allocate essential raw materials to a manufacturing plant (when other manufacturers similarly situated are receiving allocations) may force a shutdown of the plant. If the plant has no alternate uses, its entire value is the present value of the prospective earnings after the lifting of the restrictions upon allocation-the value of the "right to retain." Ignoring this, its present value is zero. There is no question that the closed plant suffers a complete loss of what would be current profits, as well as out-of-pocket expenses and depreciation charges, for the time it is forced to remain idle. But "[i]t is not sufficient that damages have resulted or that hardships have occurred. War inevitably produces hardships, suffering, and losses, some of which cannot be measured in money. Legitimate war powers must be exercised, whatever the cost."38 Thus, ". . .when governmental powers are legitimately exercised for the public good, and the injury complained of is only incidental to their exercise, there is no taking of property for the public use." $" 39$

In refusing to compensate for the destruction of the value of a plant's production during the enforcement of restrictions, the courts employ a distinction between "incidental damages," which cannot be compensated for, and a physical "taking" which must be compensated for. ${ }^{40}$ Under the present analysis, which ignores the value of the right to retain, not only the destruction of value incidental to the lawful exercise of regulatory powers, but also the direct physical taking of property the value of which has been so destroyed, would be noncompensable. However, in the extreme case under consideration, where the "present" value (the only alternative price presently available) is zero, it is

${ }^{88}$ St. Regis Paper Co. v. United States, 76 F. Supp. 83 I, $833^{r}$ (Ct. Cl., I948), cert. den. 335 U.S. 8 I5 (1948).

${ }^{39}$ Morrisdale Coal Co. v. United States, 55 Ct. Cl. 3 ro, 3 r6 (r920), aff'd 259 U.S. I88 (I922), quoted in St. Regis Paper Co. v. United States, 76 F. Supp. 83I, 833-34 (Ct. Cl. I948), cert. den. 335 U.S. 815 (I948).

10 A discussion of the concept of "taking" is contained in Cormack, Legal Concepts in Cases of Eminent Domain, 4I Yale L.J. 22I (r93r). It is there urged that if condemnees are to be fully compensated and the losses inflicted in promoting the "public use" are to be distributed throughout the community, the concept of "taking" must not be restricted to a physical meaning. 
unlikely that this analysis would be rigorously applied by the courts. In this case, no more than in the other cases, can the value of the right to retain be determined. But it seems more probable that nonperishable property will have some value upon the lifting of controls, and that the controls will be lifted. The courts would undoubtedly find compensation due in such a case.

The same considerations could be applied to certain cases involving the government program prices. These prices were not directly reviewable as were the OPA ceiling prices. Consequently, where the program price is so low as to amount merely to a fiat price, the resulting situation is essentially the same as where trading is completely restricted.

If in cases like the above there is to be compensation, its measure should be free from confusion and easily determinable. In view of the completely speculative nature of retention value, the best rule-of-thumb in such circumstances would probably be to award the last quoted market price for the property, whether it be the price of a free or controlled market.

\section{MIGRATORY DIVORCE IN AUSTRALIA AND THE UNITED STATES}

Recent decisions and discussions have emphasized abundantly the acuteness of the country's interstate divorce problem. ${ }^{x}$ Perhaps a study of the fundamental aspect of the problem, the theory of "states' rights" to control divorce policy, coupled with a brief restatement of the uncertainty a "Nevada" decree casts upon subsequent legal relations of the parties may serve to accentuate its pressing nature as well as the difficulties of achieving a solution. It does not seem necessary to repeat all that has been said of attempted American solutions and the reasons for their failure. However, for the purpose of clarifying the American situation, a rather detailed discussion of the history of interstate divorce in the Commonwealth of Australia is attempted here. Although, to be sure, the Australian treatment cannot be realistically advanced as a solution for this country, the differences and similarities of the two legal systems on this problem have been phrased in terms of possible American adoption of the Australian program. The strength of this comparative method is founded on similarities between the legal systems of the two nations. Both spring from the same common law and are affected insofar as jurisdiction in divorce is concerned by similar constitu-

I Estin v. Estin, 334 U.S. 54I (I948); Williams v. North Carolina, 325 U.S. 226 (1945); Llewellyn, Behind the Law of Divorce, 32 Col. L. Rev. I28I (1932); Powell, And Repent at Leisure, 58 Harv. L. Rev. 930 (I945); Lenhoff, The Rationale of the Recognition of Foreign Divorces in New York, I6 Fordham L. Rev. 23 I (1947); J. M. Radin, The Interstate Divorce Problem, 69 N.J. L.J. 233 (r946). For an interesting decision shedding light upon early conflicts problems when states based jurisdiction variously on domicile, place where the cause of action arose, place of marriage, see Ditson v. Ditson, 4 R.I. 87 (I856). Footnote I $_{3}$ of Justice Frankfurter's dissent in Sherrer v. Sherrer, 334 U.S. 343, 364 (1948), traces briefly recent attempts to solve the problem. 